Ahmedin Lekpek

Državni univerzitet

u Novom Pazaru

alekpek@np.ac.rs

Prevod

obezbedio

autor
PRIMENJIVOST

BAZELSKIH

STANDARDA

U ISLAMSKOM

BANKARSTVU

\title{
Rezime
}

S ciljem stabilizacije bankarskog sistema na nacionalnom i globalnom nivou i sprečavanja razornih kriza koje se vrlo brzo sa finansijskog prelivaju na realni sektor, usvojeni su Bazelski standardi adekvatnosti kapitala i upravljanja rizicima, koji su implementirani u izvornoj ili delimično izmenjenoj formi u velikom broju zemalja. Rastuće prisustvo i značaj islamskih banaka uslovili su povećanu pažnju stručne javnosti prema svim aspektima poslovanja ovih finansijskih institucija. Jedan od ključnih aspekata poslovanja islamskih banaka je efikasnost održavanja adekvatnog nivoa kapitala i upravljanja rizicima. Uzimajući u obzir specifičnost islamskog finansijskog posredovanja i poslova koje islamske banke realizuju, postavlja se pitanje da li su Bazelski propisi i praksa konvencionalnih banaka u upravljanju kapitalom i rizicima primenjivi u islamskim bankama. U radu ćemo analizirati mogućnosti islamskih banaka da, ne odstupajući od bazičnih šerijatskih principa, primene Bazelske standarde prilikom strukturiranja kapitala, kontrole ispoštovanosti standarda adekvatnosti kapitala i izveštavanja o uspešnosti upravljanja kapitalom i rizicima.

Ključne reči: islam, bankarstvo, Bazelski standardi, adekvatnost kapitala, računovodstveni standardi

JEL: G21, M41 


\section{THE \\ APPLICABILITY \\ OF BASEL \\ STANDARDS \\ IN ISLAMIC \\ BANKING}

Ahmedin Lekpek

State University

of Novi Pazar

alekpek@np.ac.rs
Translation provided by the author

\section{Summary}

With the goal of stabilizing the banking system at the national and global level and preventing the devastating crises that very swiftly spill over from the financial into the real sector, the Basel standards of capital adequacy and risk management have been adopted and implemented in the original or slightly altered form in many countries. The increasing presence and significance of Islamic banks demand more attention of the professional public focused on all of the business aspects of these financial institutions. One of the key aspects of Islamic bank business is efficiency in maintaining the adequate capital level and risk management. Considering the uniqueness of Islamic financial intermediation and businesses conducted by Islamic banks, the question is raised whether the Basel regulations and practices of conventional banks in capital and risk management are applicable in the Islamic banks. It this paper we will analyze the possibilities of Islamic banks to, apply the Basel standards without deviating from the basic Sharia principles in the process of structuring their capital, monitoring their capital adequacy ratios, and reporting on their success in capital and risk management.

Keywords: Islam, banking, Basel standards, capital adequacy, accounting standards

JEL: G21, M41 


\section{Uvod}

Visina kapitala banke je jedan od glavnih kriterijuma na osnovu kojeg regulatorne vlasti, deponenti, klijenti, konkurencija i javnost procenjuju poslovne kapacitete i perspektivu banke. Kapital predstavlja finansijsku bazu neophodnu za osnivanje banke, ali i temelj za održivi rast i razvoj, privlačenje i zadržavanje klijenata i zadovoljavanje regulatornih zahteva (Rose, 2003, str. 471-472). Bazelski komitet za nadzor banaka (Basel Committee on Banking Supervision - BCBS) je upravo iz tih razloga svoj koncept zaštite i upravljanja bankarskim rizicima bazirao na kapitalu banke, tj. odnosu kapitala i aktive banke. Krajem 80-tih godina, Bazelski komitet usvaja set globalno primenjivih standarda adekvatnosti kapitala, kojima se definišu struktura kapitala, postupak utvrđivanja rizične aktive i donja granica adekvatnosti kapitala (BCBS, 1988). Tokom 90tih godina usvojeno je nekoliko amandmana na prvobitnu verziju Bazelskih standarda. Najpre su u razmatranje uzeti i finansijski derivati (BCBS, 1995), a potom je struktura kapitala proširena dodavanjem nivoa 3 i listi rizika, čije se dejstvo na poslovanje banke analizira, već zastupljenom kreditnom riziku, dodati su i tržišni rizici (BCBS, 1996). Ubrzo je usvojen i dokument koji se bavio transparentnošću poslovanja banaka (BCBS, 1998).

Izvesni nedostaci prvog seta Bazelskih standarda, podstakli su Bazelski komitet da usvoji revidirani okvir upravljanja kapitalom (BCBS, 2004). Ovaj dokument donosi značajne novine $\mathrm{u}$ vidu definisanja tri stuba adekvatnosti kapitala: stub 1 - minimalni zahtevi za kapitalom, stub 2 - nadzor nad adekvatnošću kapitala i stub 3 - tržišna disciplina. Kad je $\mathrm{u}$ pitanju stub 1, promene su izvršene kod određivanja rizikom ponderisane aktive jer je u obzir uzeta i izloženost banke dejstvu operativnog rizika i definisani su novi pristupi za utvrđivanje zahteva za kapitalom za kreditni rizik. Stub 2 je usmeren ka kontroli ispoštovanosti propisa o adekvatnosti kapitala u bankama, dok se stub 3 tiče objavljivanja informacija o poslovanju banke, neophodnih za procenu rizičnosti njenog poslovanja i adekvatnosti kapitala kojim raspolaže. Ipak, bez obzira na značajan iskorak koji je novim setom standarda napravljen, vremenom su se ukazali brojni propusti i nedorečenosti ovog seta standarda, što je naročito postalo uočljivo tokom svetske ekonomske krize. Da bi se globalni okvir upravljanja kapitalom i rizicima dodatno unapredio i bankarski sistemi učinili otpornijima na udare povremenih kriza na finansijskim tržištima, Bazelski komitet usvaja nekoliko dokumenata (BCBS, 2009, 2010, 2011, 2013) kojima povećava zahteve za kapitalom i poseban akcenat stavlja na upravljanje likvidnošću, koja je tokom krize kod većine banaka bila značajno ugrožena.

Bazelski standardi su koncipirani i usvajani shodno zahtevima konvencionalnog bankarskog poslovanja i ne prepoznaju posebnost islamskog bankarstva. Ipak, usled nepostojanja autentičnih islamskih bankarskih standarda adekvatnosti kapitala, islamske banke su primorane da koriste konvencionalne standarde. Uzimajući u obzir činjenicu da se islamske i konvencionalne banke primetno razlikuju, logično je postaviti pitanje da li islamske banke mogu primeniti Bazelske standarde $\mathrm{u}$ izvornom obliku, a da pritom ne odstupe od šerijatskih principa, bazičnih za islamsko bankarstvo. Odgovor na ovo pitanje dat je $\mathrm{u}$ članku u tri koraka. Najpre je analizirana primenjivost Bazelske procedure utvrđivanja minimalnih zahteva za kapitalom, kroz definisanje strukture kapitala i pondera rizika, potom je predstavljena praksa nadzora na kapitalom u pojedinim zemljama u kojima islamske banke posluju i, na kraju, razmatrani su izazovi primene konvencionalnih i šerijatski usklađenih standarda finansijskog izveštavanja islamskih banaka.

\section{Minimalni zahtevi za kapitalom}

Polazeći od Bazelskih standarda i specifične prirode islamskog finansijskog posredovanja, Odbor za islamske finansijske usluge (Islamic Financial Services Board - IFSB) je formulisao standarde adekvatnosti kapitala za islamske finansijske institucije, koji su 2005. godine publikovani pod nazivom "Standard adekvatnosti kapitala za institucije (izuzev osiguravajućih institucija) koje nude samo islamske finansijske usluge" (Capital Adequacy Standard for Institutions (other than Insurance 


\section{Introduction}

The amount of bank capital is one of the main criteria by which the regulatory authorities, depositors, clients, the competition and the public estimate the business capacities and possibilities of a bank. Bank capital represents the financial basis necessary for the establishment of a bank, but also a base for sustainable growth and development, attracting and keeping clients and meeting the regulatory requirements (Rose, 2003, p. 471-472). The Basel Committee on Banking Supervision (BCBS), for exactly these reasons, based its concept of protecting and managing bank risks on bank capital, i.e. the capital to assets ratio of a bank. By the end of the 1980s, the BCBS adopted a set of globally applicable capital adequacy standards, which define the capital structure, the process of determining risk weighted assets and minimum capital requirements (BCBS, 1988). During the 1990s a couple of amendments were added to the initial version of the Basel standards. Firstly, the financial derivatives were taken into consideration (BCBS, 1995), and then the capital structure was expanded by adding Tier 3, and the list of risks, whose effects on the bank's business have been analyzed was expanded by adding market risks to the already represented credit risk, (BCBS, 1996). Soon afterwards the document dealing with the transparency of banks' business was adopted, too (BCBS, 1998).

Certain shortcomings of the first set of Basel standards encouraged the Basel Committee to adopt a revised framework for capital management (BCBS, 2004). This document brought significant innovations by defining the three pillars of capital adequacy: Pillar 1 - minimum capital requirements, Pillar 2 supervisory review of capital adequacy and Pillar 3 - the market discipline. When it comes to Pillar 1, the changes were made in respect of determining the risk weighted assets, by taking into consideration the bank's exposure to operational risk as well, and defining the new approaches to determining credit risk capital requirements. Pillar 2 is aimed at controlling if the regulations are followed when it comes to the capital adequacy in banks, while Pillar 3 is concerned with publishing the information about the bank business, necessary for estimating its risk level and capital adequacy. However, despite the significant progress that was made with a new set of standards, numerous flaws and omissions of this set of standards occurred subsequently, which was particularly evident during the global financial crisis. In order to additionally improve the global framework of capital and risk management, and to make the banking systems more resistant to the occasional financial market shocks the Basel Committee adopted a couple of documents (BCBS, 2009, 2010, 2011, 2013) increasing the capital requirements and particularly stressing liquidity management, which was significantly jeopardized in many banks during the crisis.

The Basel standards are conceived and adopted in accordance with the conventional banking business requirements and they do not recognize the specificities of Islamic banking. However, due to the non-existence of authentic Islamic banking standards of capital adequacy, the Islamic banks are forced to use the conventional standards. Considering the fact that conventional banks and Islamic banks differ considerably, it is logical to pose a question if the Islamic banks can apply the Basel standards in their original form, without deviating from the Sharia principles, which are essential for Islamic banking. The answer to this question is explained in this paper in three steps. First, the paper analyzes the applicability of the Basel procedure for determining the minimum capital requirements through defining the capital structure and risk weights, then it presents the capital supervision practice in certain countries where Islamic banks exist, and finally, it examines the challenges of using the conventional and Sharia compliant standards of financial reporting by Islamic banks.

\section{Minimum Capital Requirements}

Starting from the Basel standards and the specific nature of the Islamic financial intermediation, the Islamic Financial Services Board (IFSB) formulated the capital adequacy standards for Islamic financial institutions, which were published in 2005, as ,"The Capital Adequacy Standard for Institutions (other than Insurance Institutions) offering only 
Institutions) offering only Islamic Financial Services). U ovom dokumentu je definisan samo Stub 1 adekvatnosti kapitala (minimalni iznos obaveznog kapitala), dok Stubovi 2 i 3 nisu bili predmet analize. Utvrđivanje adekvatnosti kapitala temelji se na definisanju regulatornog kapitala i rizikom ponderisane aktive. Odbor za islamske finansijske usluge propisuje da minimalna stopa obaveznog kapitala za islamske finansijske institucije mora biti $8 \%$ i da je nivo 2 kapitala ograničen na $100 \%$ nivoa 1 kapitala. Standardima koje je formulisao Odbor nisu definisani elementi nivoa 1 i nivoa 2 kapitala.

Pojedini teoretičari islamskog bankarstva (Obaidullah, 1997, str. 50) smatraju da je prirodno da vlasnički kapital bude element nivoa 1 kapitala banke, dok investicioni depoziti, po svojim odlikama, pre mogu biti element nivoa 2 kapitala banke. Ipak, uključivanje investicionih depozita u nivo 2 kapitala, neprikladnim smatraju kako Računovodstvena i revizorska organizacija za islamske finansijske institucije (Accounting and Auditing Organization for Islamic Financial Institutions - AAOIFI), tako i dobar deo stručne javnosti (Grais \& Kulathunga, 2007). Analizom strukture regulatornog kapitala u više islamskih banaka (Abu Dhabi Islamic Bank, Al Rajhi Bank, Bahrain Islamic Bank, Dubai Islamic Bank, Qatar Islamic Bank), zaključili smo da nivo 1 kapitala, uz manja odstupanja, ima gotovo identične elemente kod svih posmatranih islamskih banaka. Međutim, primetno je da se struktura nivoa 2 kapitala razlikuje kod različitih islamskih banaka, pri čemu pojedine banke ne navode primenjenu strukturu ovog nivoa kapitala, što ukazuje na neusklađenost regulatornih propisa i prakse islamskih banaka u različitim zemljama. Sem toga, Bazelska formulacija strukture nivoa 2 kapitala banke uključuje pojedine šerijatski nepodobne elemente, poput kamatonosnih zajmova i preferencijalnih akcija, koji se ne mogu naći u strukturi kapitala islamskih banaka. Na kraju, struktura nivoa 3, koji je prema Bazelskim standardima baziran na konvencionalnom zaduženju, potpuno je neprihvatljiva sa aspekta Šerijata, tako da u većini predloga strukture regulatornog kapitala islamskih banaka figuriraju samo nivo 1 i nivo 2 kapitala.
Odbor za islamske finansijske usluge (IFSB, 2005, str. 3) nije zanemario posebnost investicionih depozita islamskih banaka, kod kojih banke sa svojim deponentima ne uspostavljaju dužničko-poverilački odnos, svojstven konvencionalnim bankama, već partnerski odnos. S obzirom na to da je zaštita deponentskih uloga od rizika poslovanja banke jedna od najvažnijih funkcija kapitala, iznos obaveznog kapitala islamskih banaka treba da bude znatno niži nego u slučaju konvencionalnih banaka jer većina deponenata sa bankom deli poslovne rizike. U praksi, međutim, vlasnici investicionih deponenata često nisu spremni da dele rizik poslovanja sa bankom, pa su stoga islamske banke primorane da formiraju specijalne rezerve za osiguranje prinosa na depozite (Iqbal \& Mirakhor, 2009, str. 224-226).

Nakon određivanja regulatornog kapitala, naredni korak $\mathrm{u}$ određivanju adekvatnosti kapitala je određivanje rizikom ponderisane aktive. Prilikom primene Bazelskih metoda utvrđivanja iznosa rizične aktive, islamske banke se suočavaju sa značajnim preprekama. Naime, korišćenje standardizovanog pristupa je otežanonepostojanjemislamskih rejting agencija na osnovu čije bi se procene dodeljivali ponderi rizika plasmanima islamske banke. Usled toga, islamske banke su primorane da koriste rejtinge određene od strane konvencionalnih rejting agencija koje zanemaruju šerijatski aspekt rejtingovanja koji je za religiozne investitore skoro podjednako važan kao i ekonomski aspekt (Al-Amine, 2008, str. 14). S druge strane, napredne interne metode merenja rizika islamske banke najčešće ne mogu koristiti jer zemlje u kojima one uglavnom posluju (region Bliskog istoka) ne raspolažu adekvatnim bazama podataka o slučajevima neizvršenja obaveza od strane dužnika u prošlosti (Hassan, 2012 , str. 6). Konačno, i pored toga što su tokom poslednjih nekoliko godina razvile niz šerijatski prihvatljivih tehnika zaštite od rizika, islamske banke i dalje na raspolaganju imaju veoma ograničen set finansijskih derivativa, čijim se uspešnim korišćenjem $u$ procesu hedžinga dejstva rizika mogu ublažiti i, samim tim, umanjiti iznos obaveznog kapitala (Ariss \& Sarieddine, 2007, str. 58).

Standard koji je formulisao Odbor za 
Islamic Financial Services“. Only Pillar 1 of capital adequacy was defined in this document (minimum capital requirements), while Pillars 2 and 3 were not the subject of analysis. The process of determining capital adequacy is based on defining the regulatory capital and risk weighted assets. The IFSB demands that the minimum capital adequacy ratio for Islamic financial institutions must be $8 \%$ and that the Tier 2 capital is limited to $100 \%$ of Tier 1 capital. The standards formulated by the IFSB do not define the elements of the Tier 1 and 2 capital.

Certain theoreticians of Islamic banking (Obaidullah, 1997, p. 50) consider that it is natural for common capital to be an element of the bank's Tier 1 capital, while investment deposits, in line with their characteristics, are rather an element of Tier 2 capital. Yet, the inclusion of investment deposits in Tier 2 capital is considered inappropriate by both the Accounting and Auditing Organization for Islamic Financial Institutions (AAOIFI), and a considerable part of professional public (Grais \& Kulathunga, 2007). By analyzing the structure of regulatory capital in many Islamic banks (Abu Dhabi Islamic Bank, Al Rajhi Bank, Bahrain Islamic Bank, Dubai Islamic Bank, Qatar Islamic Bank), we have concluded that Tier 1 capital, with small deviations, possesses almost identical elements as all the observed Islamic banks. However, it is noticeable that the structure of Tier 1 capital varies from one Islamic bank to another, whereby some banks do not state the applied structure of this Tier, which indicates the inconsistency of regulations and practice of Islamic banks in different countries. Besides that, the Basel formulation of the structure of Tier 2 capital includes certain elements inappropriate by the Sharia, such as the interest bearing loans and preferred stocks, which cannot be found in the capital structure of Islamic banks. Finally, the structure of Tier 3, which is based on conventional debt according to the Basel standards, is ultimately unacceptable by the Sharia, and, therefore, most of the suggested regulatory capital structures of Islamic banks only include Tier 1 and 2 capital.

The Islamic Financial Services Board (IFSB, 2005, p. 3) did not neglect the uniqueness of Islamic bank investment deposits, in which banks do not establish the debtor-creditor relationship with their depositors, typical for conventional banks, but instead form a partnership. Considering that the protection of deposits from the bank's business risks is one of the most important functions of capital, the amount of mandatory capital of Islamic banks needs to be considerably lower than in the case of conventional banks, because most of the depositors share the business risks with the bank. In practice, however, the holders of investment deposits are often unwilling to share the business risks with the bank, which is why Islamic banks are forced to create special reserves for insuring the return on deposits (Iqbal \& Mirakhor, 2009, p. 224-226).

After determining the regulatory capital, the next step in defining capital adequacy is determining risk weighted assets. In applying the Basel methods for determining risk weighted assets, Islamic banks face major obstacles. Namely, using the standardized approach is hard due to the lack of Islamic rating agencies that would give the basis for assigning risk-weights to the investments of a particular Islamic bank. In line with this, Islamic banks are forced to use the ratings determined by conventional rating agencies that neglect the Sharia aspect of rating, which is, for religious investors, almost as important as the economic aspect (Al-Amine, 2008, p. 14). On the other hand, advanced internal ratingsbased methods of measuring risks of an Islamic bank often cannot be used since the countries in which they mainly operate (the Middle East region) do not acquire the adequate data on the past cases of the debtor's default (Hassan, 2012, p. 6). Finally, despite having a number of Sharia risk protection techniques developed, Islamic banks still have a very limited set of financial derivatives which could be successfully used in the hedging process to mitigate the risk effects, thereby decreasing the amount of mandatory capital (Ariss \& Sarieddine, 2007, p. 58).

The standard formulated by the IFSB defines minimum capital requirements for credit and market risk for the following Islamic financial and investment instruments (IFSB, 2005, p. 2): 1. Murābahah and Murābahah for the Person Ordering the Purchase, 2. Salam and Parallel Salam, 3. Istisnā'and Parallel Istisnā, 4. Ijārah and Ijārah Muntahia Bittamleek, 5. Mushārakah 
islamske finansijske usluge definiše minimalne zahteve za kapitalom za kreditni i tržišni rizik za sledeće islamske finansijske i investicione instrumente (IFSB, 2005, str. 2): 1. murabehu i murabehu za naručioca kupovine, 2. selem i paralelni selem ugovor, 3 . istisna' i paralelni istisna' ugovor, 4. idžaru i idžaru sa otkupom, 5. mušareku i umanjujuću mušareku, 6. mudarebu i 7 . sukuk koji se drži kao investicija. Određivanje minimalnih zahteva za kapitalom za operativni rizik, islamske banke mogu vršiti primenom pristupa osnovnog indikatora ili standardizovanog pristupa, pri čemu se kao indikator izloženosti koristi bruto dobitak. Odbor definiše bruto dobitak kao zbir neto dobitka od aktivnosti finansiranja, neto dobitka od investicionih aktivnosti i prihoda po osnovu naknada i provizija, umanjen za iznos udela u profitu vlasnika investicionih depozita. Odbor preporučuje da se zahtevi za kapitalom za tržišni i za operativni rizik pomnože sa 12,5 .

Uključivanjem dobijenih vrednosti regulatornog kapitala i rizikom ponderisane aktive $\mathrm{u}$ formulu racia adekvatnosti kapitala, utvrđuje se adekvatnost kapitala konkretne islamske banke. Odbor za islamske finansijske usluge je razvio dve formule za izračunavanje racia adekvatnosti kapitala: standardnu i supervizorsku diskrecionu formulu.
Standardna formula

\section{PROPISANI KAPITAL}

Ukupna rizikom ponderisana aktiva (kreditni, tržišni i operativni rizik)

rizikom ponderisana aktiva finansirana putem investicionih depozita (kreditni i tržišni rizik)
U standardnoj formuli, investicionim depozitimasuobuhvaćeneirezervezaosiguranje prinosa na depozite (rezerve za izjednačavanje dobiti i rezerve rizika ulaganja). Supervizorska diskreciona formula, s druge strane, pruža znatno bolji uvid u način određivanja rizikom ponderisane aktive i tretiranja aktive finansirane iz investicionih depozitnih izvora i investicionih rezervi (rezervi za izjednačavanje dobiti i rezervi rizika ulaganja). S obzirom na to da su vlasnici ovih depozita partneri banke, Odbor je procenio da se aktiva finansirana iz ovih izvora mora posebno tretirati, pa se stoga deo iznosa ove aktive oduzima od ukupne rizikom ponderisane aktive. U supervizorskoj diskrecionoj formuli primetan je faktor $\alpha$. Ovaj faktor predstavlja deo aktive finansirane putem opštih investicionih depozita i njegovu vrednost određuju regulatorne vlasti. Ovim faktorom se određuje i iznos rizikom ponderisane imovine finansirane investicionim rezervama koji se oduzima od ukupne rizikom ponderisane aktive.

\section{Nadzor nad adekvatnošću kapitala}

Izvor: IFSB (2005, str. 51)
Efikasnost

kapitalom upravljanja uslovljena je postojanjem standarda adekvatnosti kapitala i sistema konstantne kontrole ispoštovanosti ovih standarda u bankama. U islamskom bankarskom sistemu trenutno ne postoje opšteprihvaćena pravila koja treba da uređuju 
and Diminishing Mushārakah, 6. Mu®ārabah and 7. Sukūk held as investment. Islamic banks can determine the minimum capital requirements for operational risk by using the basic indicator approach or the standardized approach, using the gross income as a proxy indicator for the operational risk exposure. The IFSB defines gross income as a sum of the net income from financing activities, the net income from investment activities, and the fee income (commission and agency fee), deducted by the investment account holders' share of income. The IFSB suggests multiplying the capital requirements for market risk and operational risk by 12.5 .

By incorporating the obtained values of regulatory capital and risk weighted assets into the capital adequacy ratio formula, the capital adequacy of a particular Islamic bank is determined. The IFSB has developed two capital adequacy ratio formulas: the standard formula and the supervisory discretion formula.

Standard formula

ELIGIBLE CAPITAL

Total Risk-Weighted Assets (Credit+ Market Risks) Plus Operational Risks Risk-Weighted Assets funded by PSIA* (Credit + Market Risks)

* Profit Sharing Investment Accounts

Source: IFSB (2005, p. 51)

Supervisory discretion formula

ELIGIBLE CAPITAL

Total Risk-Weighted Assets (Credit + Market Risks) Plus Operational Risks

Risk-Weighted Assets funded by Restricted PSIA (Credit + Market Risks)

$(1-\alpha) \times($ rizikom ponderisana aktiva finansirana putem opštih inv. depozita) (kreditni i tržišni rizik)

$\alpha \times$ (Risk-Weighted Assets funded by PER and IRR ${ }^{*}$ of Unrestricted PSIA (Credit + Market Risks))

*PER - Profit Equalization Reserves; IRR - Investment Risk Reserves

Source: IFSB $(2005$, p. 51)

In the standard formula, investment deposits also cover the reserves for insuring the return on deposits (profit equalization reserves - PER and investment risk reserves - IRR). The supervisory discretion formula, on the other hand, provides a considerably better insight in the method of determining risk-weighted assets and the treatment of the assets funded by investment deposit sources and reserves. Considering that the owners of these deposits are the bank's partners, the IFSB estimated that the assets funded by these sources must be separately treated, which is why a part of the amount of the assets is deducted from the total risk-weighted assets. In the supervisory discretion formula the factor $\alpha$ is noticeable. This factor represents a part of the assets funded by the general investment deposits and its value is determined by the regulatory authorities. The amount of risk-weighted assets funded by investment reserves is also determined by this factor being deducted from the total riskweighted assets.

\section{Supervisory Review of Capital Adequacy}

The efficiency of capital management is conditioned by the existence of capital adequacy standards and the system of constant supervision of compliance with these standards in banks. In the Islamic banking system, currently there are no generally accepted rules to regulate this sphere and form a basis for conducting the supervisory review of capital adequacy in all Islamic banks. The legal establishment of Islamic banking is different from country to country. One group of countries (Iran, Pakistan, Sudan, UAE, Turkey, Yemen and Malaysia) regulated the Islamic banking with their special law, whereas the other group (Bahrain, Qatar, Saudi Arabia, Egypt and Jordan), not having a special law on Islamic banking, regulated it with the law that applies to all banks in these countries (Karim, 2001, p. 182-183). Therefore, 
ovu oblast i stvore osnovu za sprovođenje nadzora nad adekvatnošću kapitala u svim islamskim bankama. Zakonsko uređenje islamskog bankarstva veoma se razlikuje od zemlje do zemlje. Jedna grupa zemalja (Iran, Pakistan, Sudan, UAE, Turska, Jemen i Malezija) islamsko bankarstvo je uredila posebnim zakonom, dok drugu grupu čine zemlje (Bahrein, Katar, Saudijska Arabija, Egipat i Jordan) koje nemaju poseban zakon o islamskom bankarstvu, već ovu oblast uređuju zakonom koji važi za sve banke u tim zemljama (Karim, 2001, str. 182-183). Samim tim, organizacija kontrole poslovanja islamskih banaka, nadzor nad adekvatnošću kapitala, kao i ovlašćenja supervizora koji su zaduženi za kontrolu adekvatnosti kapitala razlikuju se od zemlje do zemlje. Standard adekvatnosti kapitala koji je formulisao Odbor za islamske finansijske usluge ne bavi se nadzorom nad adekvatnošću kapitala.

Centralna banka Malezije (Bank Negara Malaysia) je jedna od retkih institucija koja je preduzela konkretne korake $u$ ovoj oblasti i definisala Stub 2 za islamske banke. Centralna banka Malezije je nadzor nad adekvatnošću kapitala $\mathrm{u}$ islamskim bankama uredila setom standarda pod nazivom „Okvir adekvatnosti kapitala za islamske banke - interni proces procene adekvatnosti kapitala (stub 2)“ (Capital Adequacy Framework for Islamic Banks Internal Capital Adequacy Assessment Process (Pillar 2)). Ovim dokumentom je predviđen dvostruki nadzor nad adekvatnošću kapitala islamskih banaka, koji treba da vrše upravni organi samih banaka (interna procena) i supervizori određeni od strane centralne banke (eksterna procena). Od upravljačkih struktura islamskih banaka se očekuje da kreiraju efikasan sistem identifikacije, merenja i ublažavanja dejstva rizika $i$, shodno procenjenoj rizičnosti svog poslovanja, formiraju i održavaju kapital prema važećim propisima. Drugi deo procesa kontrole adekvatnosti kapitala sprovodi se eksterno od strane supervizora koji vrše kontrolu internog procesa procene adekvatnosti kapitala. Zadatak supervizora je da procene uspešnost uprave islamske banke u održavanju adekvatnog nivoa kapitala. Svoju procenu supervizori predočavaju centralnoj banci, koja ima mogućnost da interveniše u slučaju kada kapital u bankama nije na zahtevanom nivou ili postoji opasnost da kapital u dogledno vreme padne ispod tog nivoa. Posebno je kritična situacija kada banke, ulazeći u potencijalno visokoprinosne, ali i veoma rizične poslovne aranžmane, povećavaju udeo rizične aktive $\mathrm{u}$ ukupnoj aktivi, a da pritom taj rast nije praćen potrebnim povećanjem kapitala.

\section{Tržišna disciplina}

Finansijsko izveštavanje konvencionalnih finansijskih institucija usklađeno je sa međunarodnim standardima finansijskog izveštavanja. Međutim, aktuelni međunarodni standardi finansijskog izveštavanja ne prepoznaju specifičnost islamskih finansijskih instrumenata. Njihovom primenom $u$ finansijskom izveštavanju islamskih banaka, prikazi islamskih finansijskih transakcija i s njima povezanih prihoda i rashoda pokušavaju se uklopiti u postojeće kalupe konvencionalnih finansijskih aranžmana, zbog čega njihova specifičnost ostaje skrivena. Usled toga, finansijski izveštaji islamskih banaka postaju netransparentni i teško uporedivi, a univerzalnost islamskih banaka je neadekvatno prikazana (Archer \& Karim, 2007, str. 303-304). Za islamske banke, transparentno finansijsko izveštavanje je posebno važno, jer one samo kvalitetnim i redovnim upoznavanjem javnosti sa svojim poslovanjem i rizicima sa kojima se susreću, mogu privući nove deponente, sa kojima dele dobitak i gubitak, investitore i klijente i eliminisati predrasude koje prate njihovo poslovanje (Ariffin, Archer \& Karim, 2007, str. 168). Imperativ transparentnosti finansijskog izveštavanja islamskih banaka je tokom poslednjih godina sve izraženiji, usled činjenice da islamske banke internacionalizuju svoje poslovanje i u svoj portfolio unose sofisticirane finansijske proizvode, čime njihovo poslovanje postaje predmet novih regulatornih propisa (Hassan \& Chowdhury, 2004, navedeno u Hassan \& Dicle 2005, str. 9-10). S druge strane, insistiranje na doslednoj primeni konvencionalnih standarda finansijskog izveštavanja, koje je praksi u islamskih banaka veoma teško sprovesti, dovodi do situacije da islamske banke selektivno primenjuju pojedine konvencionalne standarde ili delove standarda 
the organization of control of the Islamic banks' business, the supervision of capital adequacy, as well as the authorization of supervisors in charge of capital adequacy control, vary from country to country. The capital adequacy standard formulated by the IFSB does not deal with the supervision of capital adequacy.

The Central Bank of Malaysia (Bank Negara Malaysia) is one of the rare institutions to take concrete actions in this sphere and define the Pillar 2 for Islamic banks. The Central Bank of Malaysia regulated the supervision of capital adequacy in Islamic banks with a set of standards called "The Capital Adequacy Framework for Islamic Banks - Internal Capital Adequacy Assessment Process (Pillar 2)“. This document implies the double supervision of capital adequacy in Islamic banks, which should be conducted by the governing bodies of the banks themselves (internal assessment) and supervisors chosen by the central bank (external assessment). The management of Islamic banks is expected to create an efficient system of identification, assessment and reduction of risk effects and, in accordance with the estimated business risks, form and manage capital according to the valid regulations. The second part of the capital adequacy control is conducted externally by the supervisors who control the internal process of capital adequacy assessment. The supervisors' task is to estimate the success of the Islamic bank's administration in maintaining capital adequacy. The supervisors present their assessments to the central bank, which can make an intervention if the bank's capital is not at the requested level or if there is a danger it might not be in the foreseeable future. The situation is particularly critical when the banks, entering very risky business arrangements with potentially high yields, increase the share of risk-weighted assets in their total assets, without a necessary capital increase.

\section{Market Discipline}

Financial reporting of conventional financial institutions is coordinated with the international financial reporting standards. However, the current international financial reporting standards do not recognize the uniqueness of Islamic financial instruments. Using them in financial reporting of Islamic banks, the displays of Islamic financial transactions including the incomes and expenses, attempt to fit in the already existent patterns of conventional financial arrangements, which is why their uniqueness remains hidden. As a result, the financial reports of Islamic banks become nontransparent and hardly comparable, and universality of Islamic banks inadequately presented (Archer \& Karim, 2007, p. 303-304). For Islamic banks, the transparency of financial reports is especially important, because they can attract new depositors, with whom they share profit and loss, new investors and clients only by informing the public about their business and the risks they meet on a regular basis, thereby eliminating the stereotypes accompanying their business (Ariffin, Archer \& Karim, 2007, p. 168). The transparency imperative of financial reporting in Islamic banks has become more and more prominent during the past few years, due to the fact that Islamic banks have internationalized their business and included some sophisticated financial products in their portfolios, which has made their business a matter of new regulations (Hassan \& Chowdhury, 2004, cited in Hassan \& Dicle 2005, p. 9-10). On the other side, insisting on the adoption of the conventional financial reporting standards, which is very difficult to conduct in Islamic banks, resulted in a situation where Islamic banks selectively use certain conventional standards or their segments considered to be applicable to some of their business transactions, which is why financial reports of different Islamic banks are often impossible to compare (Archer \& Karim, 2007, p. 304).

In order to overcome the problems in financial reporting of Islamic financial institutions, the Islamic Development Bank initiated the establishment of the Accounting and Auditing Organization for Islamic Financial Institutions (AAOIFI), as an institution specialized for the development and enhancement of the financial reporting standards of Islamic financial institutions. This institution helps Islamic banks in making their financial reports by defining the accounting, auditing and Sharia principles for Islamic banks (Ariffin, 2005, p. 87-88). The goal 
za koje smatraju da su primenjivi kod pojedinih poslovnih transakcija, zbog čega su finansijski izveštaji različitih islamskih banaka često neuporedivi (Archer \& Karim, 2007, str. 304).

Da bi se prevazišli problemi u finansijskom izveštavanju islamskih finansijskih institucija, na inicijativu Islamske razvojne banke, osniva se Računovodstvena i revizorska organizacija za islamske finansijske institucije, kao institucija specijalizovanazarazvojiunapređenjestandarda finansijskog izveštavanja islamskih finansijskih institucija. Postojanje ove institucije pomaže islamskim bankama u sastavljanju finansijskih izveštaja putem definisanja računovodstvenih, revizorskih i šerijatskih principa za islamske banke (Ariffin, 2005, str. 87-88). Ova institucija ima za cilj da pomogne islamskim bankama $\mathrm{u}$ razvijanju adekvatne prakse izveštavanja usklađenih sa potrebama klijenata, posebno investicionih deponenata, i poslovnih partnera, kao i zahtevima regulatornih vlasti, vezanih za rizičnost poslovanja i adekvatnost kapitala (Sundararajan, 2007, str. 137).

Međutim, u većini zemalja u kojima funkcioniše islamsko bankarstvo koncipirani su nacionalni računovodstveni standardi za islamske finansijske institucije primena AAOIFI standarda nije obavezna (Faizullah, 2009, str. 94-95). Očigledno je da su regulatorne vlasti zemalja u kojima islamske banke posluju zanemarile brojne prednosti primene AAOIFI standarda, poput transparentnosti i uporedivosti finansijskih izveštaja islamskih banaka i relevantnosti i pouzdanosti informacija koje bi ti izveštaji korisnicima ponudili (Karim, 2001, str. 189). Uspešnost Računovodstvene i revizorske organizacije u daljem razvoju okvira finansijskog izveštavanja islamskih finansijskih institucija će zavisiti od podrške koju ona dobije od država u kojima funkcionišu islamske banke, odnosno njihovih regulatornih tela. Ta podrška se prvenstveno ogleda u donošenju posebnih propisa i računovodstvenih standarda koji bi bili potpuno usklađeni sa AAOIFI standardima i koje bi islamske banke morale poštovati.

$S$ druge strane, kritičari primene AAOIFI standarda smatraju da će finansijski izveštaji pripremljeni prema ovim standardima biti nerazumljivi za većinu nacionalnih i međunarodnih regulatornih agencija i potencijalnih poslovnih partnera islamskih banaka, usled čega će poslovanje islamskih banaka biti otežano, a akcije i druge hartije od vrednosti koje one emituju, potcenjene (Archer \& Karim, 2007, str. 307). U praksi se, međutim, pokazalo da, izuzev određenih AAOIFI standarda, čija je svrha adekvatno prikazivanje šerijatski usklađenih ugovora, usaglašenost između većine AAOIFI standarda i međunarodnih računovodstvenih standarda finansijskog izveštavanja je primetna (Archer \& Karim, 2007, str. 308). Ipak, svest o potrebama islamskih banaka postoji, što dokazuje odluka o uključivanju generalnog sekretara Odbora za islamske finansijske usluge u Savetodavni odbor za standarde (International Financial Reporting Standards Advisory Council), čime je omogućen uticaj islamskog finansijskog sektora na definisanje budućih međunarodnih računovodstvenih standarda (Archer \& Karim, 2007, str. 308). Iako razvoj novih, potrebama islamskih banaka prilagođenih računovodstvenih standarda, zahteva dodatne napore, koristi koje će se time ostvariti, poput unapređenja računovodstvene prakse islamskih banaka, pouzdanosti i uporedivosti finansijskih izveštaja (Hassan \& Dicle, 2005, str. 10), to itekako opravdavaju. Štaviše, pojedini teoretičari islamskog bankarstva (Kahf, 2005, str. 317) ističu da unapređenje transparentnosti poslovanja islamskih banaka ne donosi ništa više praktičnih i teoretskih poteškoća nego unapređenje transparentnosti poslovanja konvencionalnih banaka.

\section{Zaključak}

Primena Bazelskih standarda adekvatnosti kapitala u islamskim bankama nosi brojne izazove, od kojih se pojedini ne mogu prevazići bez delimične modifikacije Bazelskih pravila i prilagođavanja potrebama i prirodi islamskih banaka. Islamske banke mogu samo delimično primeniti Bazelsku strukturu regulatornog kapitala jer jedino struktura nivoa 1 kapitala može biti korišćena u islamskim bankama, dok nivo 2 i nivo 3 kapitala nije moguć formirati $\mathrm{u}$ islamskoj banci po Bazelskim propisima. Razlog tome je što se nivoi 2 i 3 kapitala sastoje od instrumenata koji su šerijatski neprihvatljivi. Ovaj problem islamske banke mogu rešiti na dva načina: 1 . formiranjem kapitala koji se 
of this institution is to help Islamic banks in developing the adequate reporting practices tailored to their clients' needs, especially investment depositors and business partners, and in line with the regulatory authorities' requests concerning the business risks and capital adequacy (Sundararajan, 2007, p. 137).

However, in most countries where Islamic banks are operating, the national accounting standards for Islamic financial institutions are established, and the application of the AAOIFI standards is not mandatory (Faizullah, 2009, p. 94-95). Obviously, the regulatory authorities in the countries in which Islamic banks do business have neglected many advantages of the AAOIFI standards, such as the transparency and comparability of financial reports of Islamic banks and the relevance and reliability of the information the reports would be offering to the users (Karim, 2001, p. 189). The success of the AAOIFI in further developing the financial reporting of Islamic financial institutions will depend on the support it gets from the countries in which Islamic banks do business, i.e. their regulatory bodies. Such support is evident in establishing the special regulations and accounting standards that would be in accordance with the AAOIFI standards and mandatory for Islamic banks.

On the other hand, the critics of the AAOIFI standards believe that the financial reports prepared in accordance with these standards will be incomprehensible for most of the national and international regulatory agencies and potential business partners of Islamic banks, which is why the business of Islamic banks will be hindered and their shares and other securities underrated (Archer \& Karim, 2007, p. 307). However, the practice has shown that, except for certain AAOIFI standards, whose purpose is to adequately present the Sharia compliant contracts, the compatibility between most of the AAOIFI standards and the international financial reporting standards is noticeable (Archer \& Karim, 2007, p. 308). Still, the awareness about the needs of Islamic banks exists, which is proven by the decision to include the secretary general of the IFSB in the International Financial Reporting Standards Advisory Council, thus enabling the Islamic financial sector to take part in defining the future international accounting standards (Archer \& Karim, 2007, p. 308). Although the development of new accounting standards, conditioned by the needs of Islamic banks, requests additional efforts, the achieved benefits, such as the advancement of accounting practice of Islamic banks, the reliability and comparability of financial reports (Hassan \& Dicle, 2005, p. 10), are definitely worth the effort. Moreover, some theoreticians of Islamic banking (Kahf, 2005, p. 317) point out that the advancement of transparency in the Islamic banking business brings no more practical and theoretical difficulties than the improvement of transparency in the operations of conventional banks.

\section{Conclusion}

The use of the Basel capital adequacy standards in Islamic banks entails many challenges, some of which are impossible to overcome without the partial modification of the Basel rules and the adjustment to the needs and nature of Islamic banks. Islamic banks can only partially adopt the Basel structure of regulatory capital since they can only use the structure of Tier 1 capital, while Tier 2 and 3 capital are impossible to form in Islamic banks according to the Basel regulations. The reason for this is because Tier 2 and 3 are made of instruments that are unacceptable according to Sharia. This problem can be solved in two ways: 1 . by forming capital consisting of only Tier 1 ( equity, retained profit and reserves), or 2. by structuring Tier 2 and 3 in accordance with Sharia. Most of Islamic banks chose the second solution, provided that the structure of Tier 2 is not standardized, but different in Islamic banks operating in different countries. Besides that, a sustainable solution for the structure of Tier 3 has not been discovered yet, which is why Tier 3 is rarely found in the structure of regulatory capital of Islamic banks.

In line with the Basel standards, the Islamic Financial Services Board, determined the risk weights for different types of Islamic banking operations. However, the possibility of persistently following the Basel standards while determining the risk-weighted assets of Islamic banks is very limited. That is, Islamic banks still 
sastoji samo od nivoa 1 (akcionarskog kapitala, zadržanog profita i rezervi) ili 2. strukturiranjem nivoa 2 i 3 na šerijatski prihvatljiv način. Većina islamskih banaka se odlučila za drugi način, s tim što struktura nivoa 2 nije standardizovana, već se razlikuje kod islamskih banaka iz različitih država. Sem toga, za strukturu nivoa 3 još uvek nije pronađeno održivo rešenje, tako da se nivo 3 vrlo retko može naći u strukturi regulatornog kapitala islamskih banaka.

Odbor za islamske finansijske usluge je, po uzoru na Bazelske standarde, odredio pondere rizika za različite vrste islamskih bankarskih poslova. Međutim, mogućnost dosledne primene Bazelskih standarda prilikom utvrđivanja rizične aktive islamskih banaka je veoma ograničena. Naime, islamske banke još uvek nemaju adekvatne uslove za korišćenje Bazelskih metoda merenja rizika. Primena standardizovanog pristupa otežana je usled nepostojanja islamskih rejting agencija koje bi bile sposobne da na valjan način odrede rejting islamskih banaka, uzimajući u obzir sve aspekte njihovog poslovanja. $S$ druge strane, primenu internih pristupa ograničava nedostupnost podataka koji govore o prethodnim slučajevima neizvršenja obaveza pojedinih dužnika. Takođe, Bazelski standardi ne prepoznaju specifičnost islamskih investicionih depozita i odnosa između njihovih vlasnika i islamske banke. Islamskim bankama je potrebno znatno manje kapitala za zaštitu deponenata od rizika gubitka nego konvencionalnim bankama jer vlasnici investicionih depozita dele sa bankom dobitak i gubitak iz poslovanja. Samim tim, aktiva finansirana iz investicionih depozitnih izvora ne može biti tretirana na isti način kao aktiva konvencionalnih banaka koja je finansirana kamatonosnim depozitima. Odbor za islamske finansijske usluge je $\mathrm{u}$ svom regulatornom okviru adekvatnosti kapitala uzeo u obzir ovu činjenicu i u formuli za izračunavanje adekvatnosti kapitala na poseban način tretirao aktivu koja se finansira sredstvima sa investicionih računa.

Standardima adekvatnosti kapitala, koje je formulisao Odbor za islamske finansijske usluge, nije definisan Stub 2 adekvatnosti kapitala. Na taj način, regulisanje ovog pitanja prepušteno je državama u kojima islamske banke posluju, što dodatno produbljuje problem nestandardizovanosti propisa koji regulišu poslovanje islamskih banaka. Propisi većine zemalja na potpuno isti način tretiraju adekvatnost kapitala $\mathrm{u}$ islamskim i konvencionalnim bankama. Insistiranje na doslednom sprovođenju Bazelskih standarda u islamskim bankama, bez neophodnih prilagođavanja, može biti samo kontraproduktivno. Time bi se dala prednost formi nad suštinom, jer bi islamske banke formalno ispoštovale nametnute propise, ali u suštini regulatorni kapital i rizična aktiva koji bi se definisali na taj način ne bi realno odražavali koliko su rizični plasmani banke i da li je raspoloživi kapital dovoljan za zaštitu od dejstva rizika plasmana.

Međunarodni standardi finansijskog izveštavanja, na kojima se baziraju pravila obelodanjivanja propisana Stubom 3, ne mogu se bez određenih modifikacija primeniti $\mathrm{u}$ islamskim bankama, jer oni potpuno zanemaruju šerijatske elemente islamskih finansijskih transakcija i instrumenata. Ovaj problem je delimično rešen zahvaljujući AAOIFI standardima finansijskog izveštavanja. Međutim, dugoročno održivo rešenje i standardizovana praksa finansijskog izveštavanja islamskih banaka trenutno ne postoje. Problem kod AAOIFI standarda je $\mathrm{u}$ tome što relativno mali broj zemalja priznaje ove standarde. Samim tim, islamske banke koje svoje finansijske izveštaje sastavljaju na osnovu njih, mogu imati probleme prilikom predstavljanja finansijskih izveštaja stranim partnerima koji nisu upoznati sa AAOIFI standardima ili regulatornim vlastima koje ove standarde ne priznaju. Kao i u slučaju nadzora nad adekvatnošću kapitala, insistiranje na konvencionalnoj praksi finansijskog izveštavanja u islamskim bankama može doneti više štete nego koristi. Neobelodanjivanjem šerijatskih aspekata predstavljenih transakcija, transparentnost poslovanja islamskih banaka bi bila veoma ugrožena. Ipak, uključivanje predstavnika islamskog bankarskog sektora u Savetodavni odbor za međunarodne standarde finansijskog izveštavanja budi optimizam da će u bliskoj budućnosti međunarodni računovodstveni standardi obuhvatati i standarde koji će biti posebno prilagođeni potrebama islamskih banaka. 
do not have the adequate conditions for using the Basel risk assessment methods. Using the standardized approach has been made difficult by the lack of Islamic rating agencies that would be able to determine the Islamic banks' rating, taking into consideration all of the aspects of their business. On the other hand, the use of internal ratings-based approach is limited due to the unavailability of data on the past cases of the certain debtor's default. Furthermore, the Basel standards do not recognize the uniqueness of Islamic investment deposits and the relationship between their owners and Islamic banks. Islamic banks need considerably less capital to protect their depositors from the risk of losses than conventional banks, because the owners of investment deposits share both the business profit and loss with the bank. Therefore, the assets funded by investment deposit sources cannot be treated in the same way as the assets of conventional banks funded by interest-bearing deposits. In its capital adequacy regulatory framework the IFSB took into consideration this fact and treated the assets funded by investment accounts differently in the formula for the calculation of capital adequacy.

The capital adequacy standards, formulated by the IFSB, do not define Pillar 2 of capital adequacy. This way, the regulation of this issue is left to the countries in which Islamic banks operate, which additionally expanded the problem of not having any standardized regulations for Islamic banks. The regulations in most countries treat the capital adequacy of Islamic and conventional banks in the same way. Insisting on the Basel standards' usage in Islamic banking, without some necessary modifications, can only be counterproductive. Thus the form would be favored over substance, because the Islamic banks would formally adhere to the imposed regulations, but the regulatory capital and risk-weighted assets determined that way would not realistically represent the risk levels of the bank and whether the available capital is sufficient for the protection against the investment risks.

The international financial reporting standards, which are the basis for disclosure regulations set by Pillar 3, cannot be used in Islamic banks without some modifications, since they completely neglect the Sharia elements of Islamic financial transactions and instruments. This problem has been partially solved thanks to the AAOIFI standards of financial reporting. However, a long-term sustainable solution and the standardized practice of financial reporting of Islamic banks currently do not exist. The problem with the AAOIFI standards is that a relatively small number of countries has accepted them. Therefore, the Islamic banks preparing their financial reports in accordance with these standards could have problems when presenting those financial reports to foreign partners that are not familiar with the AAOIFI standards or to the regulatory authorities that do not accept them. Just like in the case of the capital adequacy supervision, insisting on the conventional financial reporting practice in Islamic banks would cause more damage than good. Without the disclosure of the Sharia aspects of the performed transactions, the business transparency of Islamic banks would be jeopardized. Still, the involvement of an Islamic banking sector representative in the International Financial Reporting Standards Advisory Council awakes the optimism that in the near future the international accounting standards will include the standards specifically adjusted to the needs of Islamic banks. 


\section{Literatura / References}

1. Abu Dhabi Islamic Bank. 2016. Annual Report 2015. http://www.adib.ae/en/ SiteAssets/Corporate\%20Governance $\% 20$ CG\%20Annual\%20Reports/ADIB\%20 2015\%20English\%20Annual\%20Report.pdf. 10.12.2016.

2. Al-Amine, M. 2008. Sukuk Market: Inovations and Challenges. Islamic Economic Studies 15, (2): 1-22

3. Al Rajhi Bank. 2016. Annual Report 2015. http://www.alrajhibank.com.sa/en/investorrelations/documents/annual-report-2015-en. pdf. 10.12.2016.

4. Archer, S. \& Karim, R. A. A. 2007. Accounting Standards for Islamic Financial Services. U: Hassan, M. K. \& Lewis, M. K. (Ed.), Handbook of Islamic Banking (302-309). Edward Elgar Publishing Limited

5. Ariffin, N. Enhancing Transparency and Risk Reporting in Islamic Banks. Phd Thesis. School of Management, University of Surrey. 2005

6. Ariffin, N., Archer, S. \& Karim, R. A. A. 2007. Transparency and Market Discipline in Islamic Banks. U: Iqbal, M., Aly, S., \& Muljawan, D. (Ed.), Advances in Islamic Economics and Finance (153-173). Proceedings of 6th International Conference on Islamic Economics and Finance. Jeddah: Islamic Research and Training Institute, Islamic Development Bank

7. Ariss, R. T. \& Sarieddine, Y. 2007. Challenges in implementing capital adequacy guidelines to Islamic bank. Journal of Banking Regulation 9, (1): 46-59

8. Bank Negara Malaysia. Islamic Banking \& Takaful Department, Capital Adequacy Framework for Islamic Banks - Internal Capital Adequacy Assessment Process (Pillar 2).

9. http://www.bnm.gov.my/guidelines/01_ banking/01_capital_adequacy/11_ g1_002_22_pillar2.pdf. 10.11.2016.

10. Bahrain Islamic Bank. 2016. Annual Report 2015.

11. http://bisb.com/media/document/BISB $\% 20$ AR\%202015\%20English\%20(1).pdf. 10.12.2016.
12. Basel Committee on Banking Supervision. 1988. International Convergence of Capital Measurement and Capital Standards. Basel: Bank for International Settlement,. http:// www.bis.org/publ/bcbs04a.pdf. 1.11.2016.

13. Basel Committee on Banking Supervision. 1995. Treatment of Potential Exposure for Off-Balance-Sheet Items. Basel: Bank for International Settlement. http://www.bis. org/publ/bcbs18.pdf. 1.11.2016.

14. Basel Committee on Banking Supervision. 1996. Amendment to the Capital Accord to Incorporate Market Risks. Basel: Bank for International Settlement. http://www.bis. org/publ/bcbs24.pdf. 1.11.2016.

15. Basel Committee on Banking Supervision. 1998. Enhancing Bank Transparency. Basel: Bank for International Settlement. http:// www.bis.org/publ/bcbs41.pdf. 1.11.2016.

16. Basel Committee on Banking Supervision. 2004. International Convergence of Capital Measurement and Capital Standards A Revised Framework. Basel: Bank for International Settlement. http://www.bis. org/publ/bcbs107.pdf. 1.11.2016.

17. Basel Committee on Banking Supervision. 2009. Enhancements to the Basel II Framework. Basel: Bank for International Settlement. http://www.bis.org/publ/ bcbs157.pdf. 3.11.2016.

18. Basel Committee on Banking Supervision. 2009. Revisions to the Basel II Market Risk Framework. Basel: Bank for International Settlement. http://www.bis.org/publ/ bcbs158.pdf. 3.11.2016.

19. Basel Committee on Banking Supervision. 2009. Guidelines for Computing Capital for Incremental Risk in the Trading Book. Basel: Bank for International Settlement. http:// www.bis.org/publ/bcbs159.pdf. 3.11.2016.

20. Basel Committee on Banking Supervision. 2010. Basel III: A Global Regulatory Framework for More Resilient Banks and Banking Systems. Basel: Bank for International Settlement. http://www.bis. org/publ/bcbs189_dec2010.pdf. 3.11.2016. 
21. Basel Committee on Banking Supervision. 2010. Basel III: International Framework for Liquidity Risk Measurement, Standards and Monitoring. Basel: Bank for International Settlement. http://www.bis.org/publ/ bcbs189_dec2010.pdf. 3.11.2016.

22. Basel Committee on Banking Supervision. 2011. Basel III: A Global Regulatory Framework for More Resilient Banks and Banking Systems - Revised Version. Basel: Bank for International Settlement. http:// www.bis.org/publ/bcbs189.pdf. 4.11.2016.

23. Basel Committee on Banking Supervision. 2013. Basel III: The Liquidity Coverage Ratio and Liquidity Risk Monitoring Tools. Basel: Bank for International Settlement. http:// www.bis.org/publ/bcbs238.pdf. 5.11.2016.

24. Dubai Islamic Bank. 2016. Annual Report 2015. http://www.dib.ae/docs/investorrelation/financial-statement-dib-englishdec-2015.pdf. 10.12.2016.

25. Faizullah, M. Islamic banking: Issues of governance, transparency and standardization. Phd Thesis. London Metropolitan University. 2009

26. Grais, W. \& Kulathunga, A. 2007. Capital Structure and Risk in Islamic Financial Services. U: Archer, S. \& Karim, R. A. A. (Ed.), Islamic Finance: The Regulatory Challenges (6993). John Wiley and Sons (Asia)

27. Hassan, A. 2012. Jumping Hurdles: Adopting Basel II Standards in Islamic Banks. The Islamic Foundation, UK. http://www.islamic-foundation.org.uk/ islamiceconomicspdf/hassan_basel_april1. pdf. 2.10.2016.

28. Hassan, M. K. \& Chowdhury, M. A. M. 2004. Islamic Banking Regulations in Light of Basel II. Proceedings of the Fifth Harvard Research Forum on Islamic Finance.
29. Hassan, M. K. \& Dicle, M. F. 2005. Basel II and Regulatory Framework for Islamic Banks. Journal of Islamic Economics, Banking and Finance 1, (1): 1-16

30. Islamic Financial Services Board. 2005. Capital Adequacy Standard for Institutions (other than Insurance Institutions) offering only Islamic Financial Services. http://www. ifsb.org/standard/ifsb2.pdf. 7.9.2016.

31. Iqbal, Z. \& Mirakhor, A. 2009. Uvod u islamske financije: teorija i praksa. Zagreb: Mate

32. Kahf, M. 2005. Basel II: Implications for Islamic Banking. Jakarta: 6th International Conference on Islamic Economics and Banking

33. Karim, R. A. A. 2001. International accounting harmonization, banking regulation and Islamic banks. The International Journal of Accounting 36, (2): 169-193

34. Obaidullah, M. 1997. Capital Adequacy Norms for Islamic Financial Institutions. Islamic Economic Studies 5, (1\&2): 37-55

35. Rose, P. 2003. Menadžment komercijalnih banaka. Zagreb: Mate

36. Sundararajan, V. 2007. Risk measurement and disclosure in Islamic finance and the implications of profit sharing investment accounts. U: Iqbal, M., Ali, S., \& Muljawan, D. (Ed.), Advances in Islamic economics and finance (121-152). Proceedings of 6th International Conference on Islamic Economics and Finance. Jeddah: Islamic Research and Training Institute, Islamic Development Bank

37. Qatar Islamic Bank. 2016. Annual Report 2015. http://www.qib.com.qa/en/images/ English.pdf. 8.12.2016. 